\title{
Vestibular Findings in Military Band Musicians
}

\author{
Bianca Simone Zeigelboim ${ }^{1}$ Crislaine Gueber ${ }^{2}$ Thanara Pruner da Silva ${ }^{3}$ \\ Paulo Breno Noronha Liberalesso ${ }^{4}$ Claudia Giglio de Oliveira Gonçalves ${ }^{1}$ João Henrique Faryniuk ${ }^{2}$ \\ Jair Mendes Marques ${ }^{1}$ Ari Leon Jurkiewicz ${ }^{1}$
}

${ }^{1}$ Department of Speech-Language Pathology, Undergraduate Course and Communication Disorders Graduate Course at Universidade Tuiuti do Paraná-UTP, Curitiba, PR, Brazil

2 Department of Speech-Language Pathology, UTP, Curitiba, Paraná, Brazil

${ }^{3}$ Department of Surgery, Hospital das Clinicas, Universidade Federal do Paraná (UFPR), Curitiba, Paraná, Brazil

${ }^{4}$ Pequeno Principe Hospital and the Digital EEG Laboratory at the Hospital da Cruz Vermelha, Curitiba, Paraná, Brazil

Int Arch Otorhinolaryngol 2014;18:122-127.
Address for correspondence Bianca Simone Zeigelboim, PhD, Department of Otoneurology, Universidade Tuiuti do Paraná-UTP, R. Gutemberg, 99-9th floor, Curitiba, PR 80420-030, Brazil (e-mail: bianca.zeigelboim@utp.br).

\begin{abstract}
Keywords

- music

- noise effects

- dizziness

- vestibular function tests

- electronystagmography

Introduction Exposure to music is the subject of many studies because it is related to an individual's professional and social activities.

Objectives Evaluate the vestibular behavior in military band musicians.

Methods A retrospective cross-sectional study was performed. Nineteen musicians with ages ranging from 21 to 46 years were evaluated (average $=33.7$ years and standard deviation $=7.2$ years). They underwent anamnesis and vestibular and otolaryngologic evaluation through vectoelectronystagmography.

Results The most evident otoneurologic symptoms in the anamnesis were tinnitus (84.2\%), hearing difficulties (47.3\%), dizziness (36.8\%), headache (26.3\%), intolerance to intense sounds $(21.0 \%)$, and earache $(15.7 \%)$. Seven musicians $(37.0 \%)$ showed vestibular abnormality, which occurred in the caloric test. The abnormality was more prevalent in the peripheral vestibular system, and there was a predominance of irritative peripheral vestibular disorders.

Conclusion The alteration in vestibular exam occurred in the caloric test (37.0\%). There were changes in the prevalence of peripheral vestibular system with a predominance of irritative vestibular dysfunction. Dizziness was the most significant symptom for the vestibular test in correlation with neurotologic symptoms. The present study made it possible to verify the importance of the labyrinthine test, which demonstrates that this population should be better studied because the systematic exposure to high sound pressure levels may cause major vestibular alterations.
\end{abstract}

\section{Introduction}

Exposure to music is the subject of many studies because it is related to an individual's social and professional activities. ${ }^{1}$ Music has always accompanied military action as a means of communication on the battlefield and as a way to positively stimulate the troops. ${ }^{2}$ Many musicians find opportunities for professional development in military bands, ${ }^{2}$ and this requires several hours of individual and group study whose systematic exposure to high sound pressure levels can cause permanent hearing loss, ${ }^{3}$ which is a potential threat to the human ear. Studies demonstrate the potential risk of music- received

June 5, 2013

accepted

December 2, 2013
DOI http://dx.doi.org/

10.1055/s-0034-1368140. ISSN 1809-9777.
Copyright $\odot 2014$ by Thieme Publicações License terms Ltda, Rio de Janeiro, Brazil
(1) (1) $\Theta \circledast$ 
induced hearing loss in members of rock bands, parade trucks, symphony orchestras, dance bands, and individual instrumental training. 4

The musician's location in relation to the group is also an important factor that contributes to increasing sound pressure level exposure by the sound characteristics of instruments played in the vicinity of the musician and the physical aspects of the environment. ${ }^{4,5}$ The loudness increase in orchestras are due to the characteristics of the music and also brass, woodwind, and percussion instruments that achieve high sound pressure levels during presentations, as well as individual and group rehearsals. ${ }^{5,6}$

The time and intensity to which the individual is exposed are directly related to hearing damage. In the evolution of noise-induced hearing loss, individuals report difficulty in understanding speech while in particularly noisy environments, as well as hyperacusis and diplacusis. Nonauditory symptoms may be present, such as tinnitus, irritability, dizziness, headache, gastric upset, sleep disturbance, and decreased ability to concentrate, among others. ${ }^{7}$

For Ogido and colleagues, noise-induced hearing loss is preventable and can cause problems from hearing dysfunction to important vestibular alterations. ${ }^{8}$

Several structures are involved in balance, and changes in vestibular and/or auditory systems can often be the cause of body instability. ${ }^{9}$ Okamoto and Santos, ${ }^{10}$ in correlating noise with vestibular symptoms, observed that during or after exposure to noise, many patients had vestibular disorders such as vertigo with or without neurovegetative symptoms, an unsteady gait, nystagmus, fainting, and pupil dilation. It is known that the auditory impulse, before reaching the cerebral cortex, passes through several subcortical stations, which explains the presence of nonauditory effects induced by noise. $^{10}$

Individuals exposed to occupational noise often do not report dizziness and/or vertigo, probably due to the ability of the vestibular system to adapt gradually to the damage imposed by high-intensity sound. This means that alterations can occur in important labyrinthine structures without the generating any complaints. ${ }^{11}$

Teixeira and colleagues reported that high levels of sound pressure can alter balance by the activation of the saccule's sensory cells, which are sensitive to both labyrinthine and acoustic stimuli. ${ }^{12}$ Forti et al evaluated the postural responses through a stabilometric platform in individuals who were subjected to different types of music, and a significant reduction of the visual component with a consequent increase of the oscillation in the buccal and somatosensory components to the music of Mozart was observed. ${ }^{13}$ Hartman assessed college students submitted to disco and observed vertigo, tinnitus, headache, nausea, and earache in addition to hearing damage. $^{14}$

Shulman found that vestibular tests performed in patients with tinnitus suggest that primary vestibular lesion is prominent among its causes. ${ }^{15}$ Thus, these examinations may be useful in the detection of central or peripheral involvement and could help establish the site of the lesion and the correlation between tinnitus and the vestibular system.
Studies in which the focus is directed to investigations of mechanisms involving changes in body balance caused by exposure to high sound pressure levels are still scarce in both national and international literature. Thus, the aim of this study was to evaluate vestibular behavior in musicians from a military band.

\section{Materials and Methods}

This retrospective cross-sectional study evaluated 19 musicians who were members of a military band for the Army of Paraná. All were males from 21 to 46 years of age (mean age 33.7, standard deviation 7.2 years), participating in the band from 6 to 26 years (mean 16.8 years, standard deviation 5.5 years). The musical rehearsals took place every day in the morning from 8:00 to 11:00 $\mathrm{Am}$, in the battalion and in a proper location. Data were collected at the Sector of Vestibulometry of an educational institution.

Included in the research were military band musicians, regardless of instrument and time participating in the band. Subjects who showed musculoskeletal alterations that made it impossible to perform the vestibular test were excluded from the study. Musculoskeletal diseases do not allow the vestibular nystagmus and position/placement without registration necessary to move the head and body of the patient for testing.

Neurotologic symptoms and professional and personal backgrounds were investigated via questionnaire. After an otoscopic inspection, the vestibular test was performed. The musicians were subjected to the following tests that made up the exam.

Initially, vertigo and spontaneous and semispontaneous nystagmus position/positioning were checked. Then, vectoelectronystagmography used a Berger (Eletromedicina, Säo Paulo, SP, Brazil) model VN316 thermo-sensitive unit with three recording channels, a Ferrante (Säo Paulo, SP, Brazil) brand rotary chair, an EV VEC visual stimulator, and an NGR model 05 air otocalorimeter (both made by Neurograff (Eletromedicina, Säo Paulo, SP, Brazil)).

An eye movement calibration, a test for spontaneous and semispontaneous nystagmus, a pendular tracking test, an optokinetic nystagmus test, as well as prerotatory and postrotatory, precaloric and postcaloric tests were performed, according to the criteria proposed by Mangabeira-Albernaz et al. ${ }^{16}$ The caloric stimulation time for each ear with air at $42^{\circ} \mathrm{C}$ and $18^{\circ} \mathrm{C}$ was 80 seconds at each temperature. The responses were recorded with eyes closed and then with eyes open to observe the inhibitory effect of ocular fixation.

The study was approved by the Institutional Ethics Committee, protocol no. 014/2008, and the musicians were assessed after authorization from their superiors and after signing a consent form.

\section{Statistical Analysis}

Difference of proportions was used to compare the results of vestibular tests (analysis of normal and abnormal results). Fisher test was used correlation of vestibular exam and participation time in the band with more obvious neurotologic 
symptoms, and the participation time in the band with vestibular exam results. Pearson correlation coefficient was used for correlation between age and participation time in the band. Rejection of the null hypothesis was set at 0.05 or $5 \%$.

\section{Results}

The otoneurologic symptoms most evident in the medical history were tinnitus (84.2\%), hearing difficulty (47.3\%), dizziness $(36.8 \%)$, headache $(26.3 \%)$, intolerance to loud sounds (21.0\%), and earache (15.7\%). The studies on positional nystagmus, eye movement calibration, investigation of spontaneous nystagmus with eyes open and closed, semispontaneous nystagmus, pendular tracking tests, and optokinetic nystagmus showed no alterations.

Caloric tests revealed 4 cases (21.0\%) of bilateral labyrinthine hyperreflexia, 1 (5.3\%) of unilateral labyrinthine hyporeflexia, 1 (5.3\%) of unilateral labyrinthine hyperreflexia, and 1 (5.3\%) of asymmetric directional preponderance for nystagmus (DP). The test was normal in 12 cases (63.1\%).

Seven patients (37.0\%) had peripheral vestibular disorders, $6(31.7 \%)$ had irritative peripheral vestibular dysfunction, and $1(5.3 \%)$ had deficit peripheral vestibular dysfunction. The test was normal in 12 patients (63.1\%), as shown in - Table 1.

Difference of proportions test proved that there was no significant difference between the proportions of normal and abnormal scans $(p=0.1124)$.

The correlation between the results of the vestibular exam and the most evident neurotologic symptoms is shown in - Table 2. Fisher test showed a significant difference between the proportions of musicians with normal vestibular exams and abnormal vestibular exams for the symptom of dizziness ( $p=0.0017)$.

The frequency distribution relating to the type of musical instrument with the result of the vestibular exam and the most evident neurotologic symptoms is shown in -Table 3.

The correlation between the participation time in the band with the most evident neurotologic symptoms and vestibular exam results is shown in - Tables $\mathbf{4}$ and $\mathbf{5}$, respectively.

Fisher test showed that there was no significant difference between the proportion of the participation time in the band with the most evident neurotologic symptoms and the result of vestibular exam.

The correlation between age and participation time in the band resulted in a Pearson correlation coefficient of $r=0.61$ $(p=0.0055)$, a value of statistical significance.

Table 1 Vestibular exam results for military band members

\begin{tabular}{|c|l|l|}
\hline Results & $n$ & $\%$ \\
\hline NVE & 12 & 63.1 \\
\hline IPVD & 6 & 31.7 \\
\hline DPVD & 1 & 5.3 \\
\hline
\end{tabular}

Abbreviations: DPVD, deficit peripheral vestibular dysfunction; IPVD, irritative peripheral vestibular dysfunction; NVE, normal vestibular exam. Note: The proportions test demonstrated no difference between the proportions of normal and abnormal exams $(p=0.1124)$.
Table 2 Correlation between vestibular exam and most evident otoneurologic symptoms for band members

\begin{tabular}{|l|l|l|l|}
\hline Exam result & \multicolumn{2}{|l|}{$\begin{array}{c}\text { Otoneurologic } \\
\text { symptoms }\end{array}$} & $p$ \\
\hline & No & Yes & \\
\hline Tinnitus & & & \\
\hline NVE & 3 & 9 & 0.2270 \\
\hline AVE & - & 7 & \\
\hline Dizziness & & & \\
\hline NVE & 11 & 1 & $0.0017^{\text {a }}$ \\
\hline AVE & 1 & 6 & \\
\hline Difficulty hearing & & & \\
\hline NVE & 6 & 6 & 0.5700 \\
\hline AVE & 4 & 3 & \\
\hline Headache & & & \\
\hline NVE & 10 & 2 & 0.2366 \\
\hline AVE & 4 & 3 & \\
\hline $\begin{array}{l}\text { Intolerance to } \\
\text { loud noise }\end{array}$ & & & \\
\hline NVE & 8 & 4 & 0.1277 \\
\hline AVE & 7 & - & \\
\hline Earache & 5 & & \\
\hline NVE & 11 & 1 & \\
\hline AVE & 5 & 2962 \\
\hline
\end{tabular}

Abbreviations: AVE, abnormal vestibular exam; NVE, normal vestibular exam.

${ }^{a}$ Fisher test showed a significant difference between the number of musicians with NVE and AVE for dizziness.

\section{Discussion}

Medical history analysis verified the occurrence of neurotologic symptoms in the following order of precedence: tinnitus, difficulty hearing, dizziness, headache, intolerance to loud sounds, and earache. These symptoms were also observed by Gonçalves et al and Mendes and Morata, 2,6 who noted tinnitus, intolerance to loud sounds, vertigo, and hearing loss as being the most frequently reported otoneurologic complaints in alterations related to high sound pressure levels. Hartman evaluated 575 college students who frequented discos and observed vertigo, tinnitus, headache, nausea, and earache in addition to hearing loss. ${ }^{14}$ Tinnitus is a symptom of higher incidence in this study, and, according to the literature, is a functional alteration whose variable causes are not always apparent and may be related to several diseases in various parts of the body. Among the most common causes is a sudden or prolonged exposure to loud sounds. ${ }^{17}$ The origin of tinnitus always causes discussion and among the various existing theories; it is assumed to be generated by increased spontaneous neuronal activity along the auditory pathway, often associated with lesions of the inner ear and the vestibulocochlear nerve. ${ }^{17-20}$ Additionally, there may be a dynamic interaction in various regions of the 
Table 3 Frequency distribution related to type of musical instrument and results of vestibular exam and most common otoneurologic symptoms for military band members

\begin{tabular}{|c|c|c|c|c|c|c|}
\hline \multirow[t]{3}{*}{ Musical instrument } & \multicolumn{6}{|c|}{ Exam results } \\
\hline & \multicolumn{3}{|c|}{ NVE } & \multicolumn{3}{|c|}{ AVE } \\
\hline & \multicolumn{2}{|l|}{$n$} & $\%$ & \multicolumn{2}{|l|}{$n$} & $\%$ \\
\hline Bass & \multicolumn{2}{|l|}{1} & 5.3 & \multicolumn{2}{|l|}{-} & - \\
\hline Clarinet & \multicolumn{2}{|l|}{2} & 10.5 & \multicolumn{2}{|l|}{5} & 26.3 \\
\hline Percussion & \multicolumn{2}{|l|}{1} & 5.3 & \multicolumn{2}{|l|}{-} & - \\
\hline Saxophone & \multicolumn{2}{|l|}{2} & 10.5 & \multicolumn{2}{|l|}{1} & 5.3 \\
\hline Trumpet & \multicolumn{2}{|l|}{6} & 31.6 & \multicolumn{2}{|l|}{ - } & - \\
\hline Tuba & \multicolumn{2}{|l|}{-} & - & \multicolumn{2}{|l|}{1} & 5.3 \\
\hline \multirow[t]{3}{*}{ Total } & 12 & & 63.2 & 7 & & 36.8 \\
\hline & \multicolumn{6}{|c|}{ Otoneurologic symptoms $(n)$} \\
\hline & Tinnitus & $\begin{array}{l}\text { Difficulty } \\
\text { hearing }\end{array}$ & Dizziness & Headache & $\begin{array}{l}\text { Intolerance } \\
\text { to noise }\end{array}$ & Earache \\
\hline Bass & 1 & 1 & - & - & - & - \\
\hline Clarinet & 7 & 4 & 4 & 2 & - & 2 \\
\hline Percussion & - & - & - & - & - & - \\
\hline Saxophone & 3 & - & 2 & - & - & 1 \\
\hline Trumpet & 4 & 4 & - & 2 & 4 & - \\
\hline Tuba & 1 & - & 1 & 1 & - & - \\
\hline Total & 16 & 9 & 7 & 5 & 4 & 3 \\
\hline
\end{tabular}

Abbreviations: AVE, abnormal vestibular exam; NVE, normal vestibular exam.

central nervous system between the cochlear nuclei and the pons, important for the control of eye movements, with the inclusion of areas that participate in neural interaction of the pons, cerebellum, and vestibular nuclei. ${ }^{17-19}$ According to Órfão et al, ${ }^{21}$ tinnitus can be the first manifestation of a pathologic labyrinthine process present before the onset of vestibular dysfunction. Adults and children can be affected, with the prevalence of tinnitus increasing with age, and it has a high incidence associated with both exposure to noise as well as with hearing loss related to age. ${ }^{22}$

In the present study, we observed an alteration in the peripheral vestibular system, identified in the caloric test, with a predominance of irritative dysfunction. This result was consistent with Órfão et al, ${ }^{21}$ who evaluated 22 patients with complaints of tinnitus independent of hearing acuity; they observed alterations only on caloric tests with a prevalence of irritative vestibular disorder.

Teixeira et al assessed balance by examining the computerized dynamic posturography in 16 workers exposed to occupational noise of a printing company and observed alterations in balance in the assessment at all stages tested that evaluate somatosensory, visual, vestibular, and balance functions. ${ }^{12}$

Forti et al evaluated the postural responses through a stabilometric platform in 12 patients who listened to various types of music and observed a significant reduction in the visual component with a consequent increase of the oscillation in vestibular and somatosensory components while listening to the music of Mozart. ${ }^{13}$
Carrick et al used computerized dynamic posturography to evaluate 266 asymptomatic individuals after being subjected to various musical styles for 30 days. ${ }^{23}$ The examinations showed a high incidence of patients who presented alterations in balance with a risk of falling. The authors did not report how many hours per day and at what volume the patients were exposed to music, only that music by Nolwenn Leroy was the most significant.

Cassandro et al analyzed the vestibular test and incidence of vestibulocochlear symptoms in 40 individuals between 18 and 26 years old, without hearing or vestibular alterations, after listening to disco music for 3 hours at an intensity of 128 $\mathrm{dB} .{ }^{24}$ The authors evaluated subjects before and after acoustic stimulation through examination of vestibular evoked myogenic potentials and observed a significant increase in the amplitude of the vestibular evoked myogenic potentials, which indicates a possible irritant involvement to the macular receptor. This result suggests a direct action on the macular receptors for acoustic stimulation that could be the cause of the vestibular symptoms reported by individuals after exposure to intense acoustic stimuli. This research revealed a significant incidence of vestibular symptoms due to acoustic stress, which led to the hypothesis that balance disorders due to auditory stress are much more frequent.

When comparing normal and abnormal vestibular tests with the most evident neurotologic symptoms, there is a significant difference between the proportions for the symptom of dizziness. According to Teixeira et al, several structures 
Table 4 Correlation between the participation time in the band and most evident otoneurologic symptoms for military band members

\begin{tabular}{|l|l|l|l|}
\hline Participation time in band $(\mathrm{y})$ & No & Yes & $p$ \\
\hline Tinnitus & & & \\
\hline$<14$ & 1 & 9 & 0.4582 \\
\hline$\geq 14$ & 2 & 7 & \\
\hline Dizziness & & & \\
\hline$<14$ & 6 & 4 & 0.5700 \\
\hline$\geq 14$ & 6 & 3 & \\
\hline Difficulty hearing & & & \\
\hline$<14$ & 4 & 6 & 0.2422 \\
\hline$\geq 14$ & 6 & 3 & \\
\hline Headache & & & \\
\hline$<14$ & 9 & 1 & 0.5418 \\
\hline$\geq 14$ & 5 & 4 & \\
\hline Intolerance to noise & & & \\
\hline$<14$ & 9 & 1 & 0.1192 \\
\hline$\geq 14$ & 6 & 3 & \\
\hline Earache & & & \\
\hline$<14$ & 8 & 2 & 0.2492 \\
\hline$\geq 14$ & 8 & 1 & \\
\hline
\end{tabular}

Note: Fisher test showed no significant difference between the time of participation in the band and the most evident otoneurologic symptoms and with the vestibular exam result. The correlation between age and participation time in the band showed a Pearson correlation coefficient of $r=0.61(p=0.0055)$, a significant statistical value.

are involved in the process of balance, and a loss of body stability can often be related to changes in the vestibular and/ or auditory systems. ${ }^{12}$ High sound pressure levels can alter balance through the activation of the sensory cells of the saccule that are sensitive to both acoustic and labyrinthine stimuli. According to Van Eyck, ${ }^{25}$ in experimental studies in guinea pigs exposed to loud sounds, there was a direct relationship between exposure to noise and the presence of histologic lesions in the vestibular labyrinth. The most common occurrence was the rupture of a thin sheet of cells that

Table 5 Correlation between participation time in the band and the result of the vestibular exam for military band members

\begin{tabular}{|l|l|l|l|}
\hline \multirow{2}{*}{ Participation time in band $(y)$} & \multicolumn{2}{|c|}{ Exam result } & \multirow{2}{*}{$p$} \\
\cline { 2 - 3 } & NVE & AVE & \\
\hline$<14$ & 3 & 7 & 0.4300 \\
\hline$\geq 14$ & 4 & 5 & \\
\hline
\end{tabular}

Abbreviations: AVE, abnormal vestibular exam; NVE, normal vestibular exam. separates the utricle and saccule and semicircular canals of the rest of the vestibule. The wall of the saccule was broken in approximately one-fourth of guinea pigs and damaged in one-third. The sound stimulation reduced the sensitivity of the sensory organ of the semicircular canals, indicating that the utricle and saccule are susceptible to noise trauma. According to Forti et al, high sound pressure levels alter balance through the activation of the saccule, which is sensitive to both vestibular and acoustic stimuli. ${ }^{13}$

Mehlenbacher et al revealed the incidence of dizziness and visual alterations resulting from dehiscence of the superior semicircular duct after barotrauma caused by a military and/ or terrorist explosion. ${ }^{26}$ The authors reported that barotrauma is very common in war.

The correlation between the type of musical instrument with the result of vestibular tests and neurotologic symptoms showed a greater number of labyrinthine alterations for the clarinet, which agrees with the questionnaire used in the interview that showed that the highest number of otoneurologic complaints were for musicians who played the clarinet and trumpet. Mendes and Morata reported that in bands, the most common musical instruments are brass, woodwinds, and percussion, which reach high sound pressure levels during presentations and practice for both individuals and groups, causing neurotologic disorders with hearing loss, intolerance to loud sounds, dizziness, and tinnitus being the most common. ${ }^{6}$

The analysis of participation time in the band with the most evident neurotologic symptoms and the result of vestibular test showed no significant results. However, when age was analyzed with the participation time in the band, a significant result was shown, indicating that the participation time in the band increases with the age of its members. This is a feature of the professional soldier who joins the army while still young and continues in the career. ${ }^{2}$ In the present study, the average participation time in the band was 16.8 years, with over 10 years of exposure to loud music. According to Mendes et al, ${ }^{27}$ hearing loss caused by exposure to high sound pressure levels reaches its maximum in the first 10 to 15 years of exposure, which characterizes this population as being at risk for future vestibulocochlear problems.

\section{Conclusion}

Vestibular alterations were found in the caloric test, and there was a prevalence of alterations for the peripheral vestibular system with a predominance of irritative vestibular dysfunction. Dizziness was the most significant symptom in correlation of the vestibular test with neurotologic symptoms.

This study showed the importance of the vestibular test and points out that the military band member population should be further investigated, because the systematic exposure to high sound pressure levels can cause important vestibular alterations.

\section{References}

1 Amorim RB, Lopes AC, Santos KTP, Melo ADP, Lauris JRP. Alterações auditivas da exposição ocupacional em músicos. Int Arch Otorhinolaryngol 2008;12(3):377-383 
2 Gonçalves CGO, Lacerda ABM, Zocoli AMF, Oliva FC, Almeida SB, Iantas MR. Percepção e o impacto da música na audição de integrantes da banda militar. Rev Soc Bras Fonoaudiol 2009; 14(3):515-520

3 Namuur FABN, Fukuda Y, Onishi ET, Toledo RN. Avaliação auditiva em músicos da Orquestra Sinfônica Municipal de São Paulo. Braz J Otorhinolaryngol 1999;65(5):390-395

4 Schmidt JM, Verschuure J, Brocaar MP. Hearing loss in students at a conservatory. Audiology 1994;33(4):185-194

5 Kähäri KR, Axelsson A, Hellström PA, Zachau G. Hearing assessment of classical orchestral musicians. Scand Audiol 2001;30(1):13-23

6 Mendes MH, Morata TC. Exposição profissional à música: uma revisão. Rev Soc Bras Fonoaudiol 2007;12(1):63-69

7 Kähärit K, Zachau G, Eklöf M, Sandsjö L, Möller C. Assessment of hearing and hearing disorders in rock/jazz musicians. Int J Audiol 2003;42(5):279-288

8 Ogido R, Costa EA, Machado HdaC. Prevalência de sintomas auditivos e vestibulares em trabalhadores expostos a ruído ocupacional. Rev Saude Publica 2009;43(2):377-380

9 Stumieks DL, George R, Lord SR. Balance disorders in the elderly. Clin Neurophysiol 2008;38(6):467-478

10 Okamoto VA, Santos VP. Outros efeitos do ruído no organismo. In: Santos VP, ed. Ruído, riscos e prevenção. São Paulo, Brazil: Hecitec; 1996:89-91

11 Mendes MH, Morata TC, Marques JM. Aceitação de protetores auditivos pelos componentes de banda instrumental e vocal. Braz J Otorhinolaryngol 2007;73(6):785-792

12 Teixeira CS, Körbes D, Rossi AG. Ruído e equilíbrio: aplicação da posturografia dinâmica em indústria gráfica. Rev CEFAC 2011; 13(1):92-101

13 Forti S, Filipponi E, Di Berardino F, Barozzi S, Cesarani A. The influence of music on static posturography. J Vestib Res 2010; 20(5):351-356

14 Hartman BT. An exploratory study of the effects of disco music on the auditory and vestibular systems. J Aud Res 1982;22(4):271-274
15 Shulman A. Vestibular test battery correlates and tinnitus in proceedings of the II International Tinnitus Seminar. J Laryngol Otol 1984;9:181-183

16 Mangabeira-Albernaz PL, Ganança MM, Pontes PAL. Modelo operacional do aparelho vestibular. In: Mangabeira-Albernaz PL, Ganança MM, eds. Vertigem. 2nd ed. São Paulo, Brazil: Moderna; 1976:29-36

17 Fukuda Y.Zumbido e suas corelações otoneurológicas. In: Ganança M, ed. Vertigem tem cura? São Paulo, Brazil: Lemo; 1998:171-176

18 Jastreboff PJ, Sasaki CT. An animal model of tinnitus: a decade of development. Am J Otol 1994;15(1):19-27

19 Sanchez TG, Zonato AJ, Bittar RSM, Bento RF. Controvérsias sobre a fisiologia do zumbido. Int Arch Otorhinolaryngol 1997;1(1):2-8

20 Ganança MM, Caovilla HH, Gazzola JM, Ganança CF, Ganança FF. Betahistine in the treatment of tinnitus in patients with vestibular disorders. Braz J Otorhinolaryngol 2011;77(4):499-503

21 Órfão CAS, Bonaldi LV, Lemos M, Floriano SL. Achados vestibulares em portadores de zumbido. Int Arch Otorhinolaryngol 2001;5(4):1-4

22 Henry JÁ, Dennis KC, Schechter MA. General review of tinnitus: prevalence, mechanisms, effects, and management. J Speech Lang Hear Res 2005;48(5):1204-1235

23 Carrick FR, Oggero E, Pagnacco G. Posturographic changes associated with music listening. J Altern Complement Med 2007;13(5): 519-526

24 Cassandro E, Chiarella G, Catalano M, et al. Changes in clinical and instrumental vestibular parameters following acute exposition to auditory stress. Acta Otorhinolaryngol Ital 2003;23(4):251-256

25 Van Eyck M. Sound-produced labyrinthine trauma. Arch Otolaryngol 1974;100(6):465-466

26 Mehlenbacher A, Capehart B, Bass D, Burke JR. Sound induced vertigo: superior canal dehiscence resulting from blast exposure. Arch Phys Med Rehabil 2012;93(4):723-724

27 Mendes MH, Koemler LA, Assencio-Ferreira VL. A prevalência de perda auditiva induzida pelo ruído em músicos de banda instrumental. Rev CEFAC 2002;4(3):179-185 